\title{
Registering with an OJS Journal
}

See the video here: https://www.youtube.com/watch?v=38a2qoZTkIQ 